Journal of Management Science (JMAS)

Volume 4. No. 4 October 2021, pp 106-112

e-ISSN: 2684-9747 https://exsys.iocspublisher.org/index.php/JMAS

\title{
The Effect Of Profitability, Liquidity, Leverage On Bond Rating Of Financial Companies
}

\author{
${ }^{1}$ Suryadi Hung, ${ }^{2}$ Ella Silvana Ginting, ${ }^{3}$ Sherly Joe \\ ${ }^{1,2,3}$ Universitas Mikroskil, Medan Jl. Thamrin No. 112, Medan Sumatera Indonesia \\ E-mail: ${ }^{1}$ suryadihung@ mikroskil.ac.id, ${ }^{2}$ ellasilvana@ mikroskil.ac.id.
}

\begin{abstract}
ARTICLE INFO
ABSTRACT

Article history:

Received: 05 August 2021

Revised: 08 September 2021

Accepted: 30 October 2021

Keywords:

Current Ratio;

Debt To Equity Ratio;

Return On Assets;

This research was ain determine and analyze the effect of Simultaneous and Partial on Current Ratio, Debt to Equity Ratio, and Return On Assets on Bond Ratings in financial sector companies on the Indonesia Stock Exchange for the 2016-2019 period. The population of this reserach is the financial sector companies as many as 94 companies. The sampling method used purposive sampling, and the number of samples obtained was 18 companies. This type of research is quantitative descriptive using multiple linear regression analysis method. The results of this research show that the variables Current Ratio, Debt to Equity Ratio, and Return On Assets simultaneously have a significant effect on the Bond Rating of financial sector companies on the Indonesia Stock Exchange (IDX) in 2016-2019. Partially, Current Ratio, Debt to Equity Ratio, and Return On Assets have a significant positive effect on Bond Ratings for financial sector companies on the Indonesia Stock Exchange (IDX) in 2016-2019.
\end{abstract}

Bond Rating.
Copyright (C) 2021 Journal of Management Science (JMAS). All rights reserved.

\section{Introduction}

The capital market is a means for companies to obtain additional funds. The capital market plays a major role The capital market is one part of Indonesia's economic growth. The capital market provides products in the form of securities such as stocks and bonds. Bonds can be said to be safer than stocks. From the financial statements, we are used to analyzing the performance and how healthy a company is.

Bonds are used as one of the information needed by investors in analyzing and estimating the level of risk contained in bond investments. Bonding returns that investors expect can be affected by bonding warnings. Investors expect companies that have low bond ratings, the higher than the expected return. Bondholders will earn interest from the bond issuer. The interest on a bond is generally called a coupon. Coupons can be received on a specified and agreed timeframe. Usually 1 to 10 years. Therefore, bonds can be referred to as long-term debt securities. In addition to the benefits of coupons, there are also benefits that can be obtained from the difference in bond prices. Liabilities can be traded in the secondary market. Liabilities can experience price increases that are difficult to predict. By increasing the price of bonds, investors can trade them on the secondary market regulated by the Indonesia Stock Exchange mechanism or transactions outside the stock exchange. Changes in bond prices in each company will not always increase, at a certain period a company may experience a decrease which can be caused by the performance of the company itself.

In 2016 the company PT Adira Dinamika Multi Finance Tbk received an idAAA rating, this company got the highest because the company is ready to pay maturing bonds with cash and cash equivalents of Rp 1.1 trillion [1]. In 2017 the company PT Bank Woori Saudara Indonesia Tbk experienced an increase in its rating from idAA+ due to a net profit of $41 \%$ worth Rp 438 billion [2]. In the same year, the company PT Bima Multi Finance failed to pay and was given the lowest rating, namely idD so that the company delayed paying its obligations amounting to Rp 1.09 trillion [3]. In 2018 the company PT Bank Bukopin Tbk received a rating downgrade from idA+ to idA- because this company revised its financial statements for bank credit card receivables [4]. In 2019 the company PT Bank Woori Saudara Indonesia Tbk received a rating upgrade from idAA+ to idAAA due to the addition of the company's capital [5].

The purpose of this study is to obtain empirical evidence regarding the effect of the Current Ratio (CR), 
Debt to Equity Ratio (DER), and Return on Assets (ROA) simultaneously or partially on the ratings of financial sector companies on the Indonesia Stock Exchange for the period 2016 - 2019.

The benefits of this research are expected to provide information for investors who invest in bonds, how the state of the company's performance on the company's bond rating. as well as assisting investors in making decisions to invest. For companies, it is expected to be a reference and information for companies, so that they can find out the steps that will be taken by financial sector companies in setting policies in making decisions with the influence of financial ratios on bond ratings and company progress. For further researchers, it is hoped that it can be used as a reference for further researchers regarding the effect measured by the Current Ratio, Debt to Equity Ratio, and Return on Assets on Bond Ratings in companies listed on the Indonesia Stock Exchange.

\section{Method}

This type of research will use a quantitative descriptive method because this study analyzing by reading tables, graphs, or numbers. The data to be used are certain quantities or figures that are definite and can be analyzed using statistics [7]. This study examines the effect of the current ratio, Debt to equity ratio, and Return on assets as independent variables and Bond Rating as the dependent variable with the object of the company listed on the Indonesia Stock Exchange which is included in the financial sector for the 2016-2019 period.

\section{Method of Collecting Data}

The data collection method in this study uses literature studies such as books and journals and documentation studies to collect company financial statements.

\section{Variable Operational Definition}

Bond rating is a description of the prospects like a bond to be purchased. The bond rating obtained will be a recommendation for creditors and investors to make funding to listed companies [6]. This variable can be seen from the rating of each company issued by PT PEFINDO. The scale used to determine bond ratings is by using a ratio scale to the rating of the bonds issued, namely:

\begin{tabular}{|c|c|c|c|c|c|}
\hline Rating & $\begin{array}{l}\text { Rating } \\
\text { Value }\end{array}$ & Rating & $\begin{array}{c}\text { Rating } \\
\text { Value }\end{array}$ & Peringkat & $\begin{array}{l}\text { Rating } \\
\text { Value }\end{array}$ \\
\hline idAAA & 17 & idA- & 11 & idBB- & 5 \\
\hline idAA+ & 16 & idBBB+ & 10 & idB+ & 4 \\
\hline idAA & 15 & idBBB & 9 & $\mathrm{idB}$ & 3 \\
\hline idAA- & 14 & idBBB- & 8 & idB- & 2 \\
\hline idA+ & 13 & idBB+ & 7 & idC & 1 \\
\hline idA & 12 & idBB & 6 & idD & 0 \\
\hline
\end{tabular}

The current ratio is one of the liquidity ratios that can show the ability of a company to meet its current obligations by using the available company's current assets. This variable can be measured using the formula:

$$
\text { Current Ratio }=\frac{\text { Current Assets }}{\text { Current Liabilities }}
$$

Debt to equity ratio is a ratio that can show how big the ratio of total debt to the total capital owned by the company. This ratio is used to measure how much the company's debt can be financed by capital. This variable can be measured using the formula :

$$
\text { Debt to Equity Ratio }=\frac{\text { Total Debt }}{\text { Total Equity }}
$$

Return on Assets is a ratio that can show the effect of total assets in obtaining profits. This variable can measure how much net profit will be generated from each rupiah of funds embedded in the company's assets. This variable can be measured using the formula :

$$
\text { Return On Asset }=\frac{\text { Net Income }}{\text { Total Assets }}
$$




\section{Data Analysis Method}

Methods of data analysis in this study using multiple regression analysis methods. Multiple regression analysis is needed in tests such as the classical assumption test which consists of several stages of testing, namely the normality test, multicollinearity test, heteroscedasticity test, and autocorrelation test. Tests in this study will be used with the use of the SPSS statistical application program ver.23.

This research will be conducted using the multiple regression analysis methods to analyze the effect of the independent variable on the dependent variable. The multiple regression equation that will be used in this study is as follows :

$$
\mathrm{Y}=\mathrm{a}+\mathrm{b}_{1} \mathrm{X}_{1}+\mathrm{b}_{2} \mathrm{X}_{2}+\mathrm{b}_{3} \mathrm{X}_{3}+\mathrm{e}
$$

$$
\begin{array}{ll}
\mathrm{Y} & =\text { Bond Rating } \\
\mathrm{a} & =\text { Constant } \\
\mathrm{b}_{1}, \mathrm{~b}_{2}, \mathrm{~b}_{3} & =\text { Regression Coefficient } \\
\mathrm{X}_{1} & =\text { Current Ratio }(\text { CR }) \\
\mathrm{X}_{2} & =\text { Debt to Equity Ratio }(\text { DER }) \\
\mathrm{X}_{3} & =\text { Return On Assets }(\text { ROA }) \\
\mathrm{e} & =\text { Error }
\end{array}
$$

\section{Results and Discussion}

\section{Descriptive Statistical Data}

Descriptive statistics are used to provide an overview of the research object that is sampled in the study. Based on data obtained from financial statements and reports on corporate bond ratings that fall into the financial sector category that was sampled in the 2016-2019 study, it can be seen that the minimum, maximum, average (mean), and standard deviation values of each variable used in research which can be shown in Table 2.

Table 2. Descriptive Statistics Descriptive Statistics

\begin{tabular}{|l|c|c|c|c|c|}
\hline & $\mathrm{N}$ & Minimum & Maximum & Mean & Std. Deviation \\
\hline Current Ratio $\left(\mathrm{X}_{1}\right)$ & 72 &, 068238 & 4,735306 & 1,26084996 &, 547861610 \\
Debt to Equity Ratio $\left(\mathrm{X}_{2}\right)$ & 72 &, 662476 & 14,748336 & 5,81082770 & 3,276597267 \\
Return On Asset $\left(\mathrm{X}_{3}\right)$ & 72 &, 000700 &, 103500 &, 02155278 &, 020068657 \\
Peringkat Obligasi (Y) & 72 & 9 & 17 & 14,46 & 2,648 \\
Valid N (listwise) & 72 & & & & \\
\hline
\end{tabular}

Based on the results of the study in Table 2, it can be seen that the descriptive statistical value of each variable during the 2016-2019 period. The current Ratio has a minimum value of 0.68238 and a maximum value of 4.735306. The industry average Current Ratio is 2 times [8]. The average value (mean) obtained is 1.26084996 with a standard deviation of 0.547861610 . The average value obtained reflects that the sample companies are considered less good at meeting current liabilities.

The Debt to Equity Ratio variable shows a minimum value of 0.662476 in 2017 and a maximum value of 14.748336. The industry average Debt to Equity Ratio is $80 \%$ [8]. The average value (mean) obtained is 5.81082770 with a standard deviation of 3.276597267. The average value obtained shows that the sample companies are considered to be able to fulfill all obligations.

The Return On Asset variable shows a minimum value of 0.000700 in 2019 and a maximum value of 14.748336. The industry average Return On Assets is 30\% [8]. The average value (mean) obtained is 0.02155278 with a standard deviation of 0.020068657 . The average value obtained shows that the sample companies are considered unfavorable because they are below the industry average.

Normality Test 


\section{Journal of Management Science (JMAS)}

Volume 4. No. 4 October 2021, pp 106-112
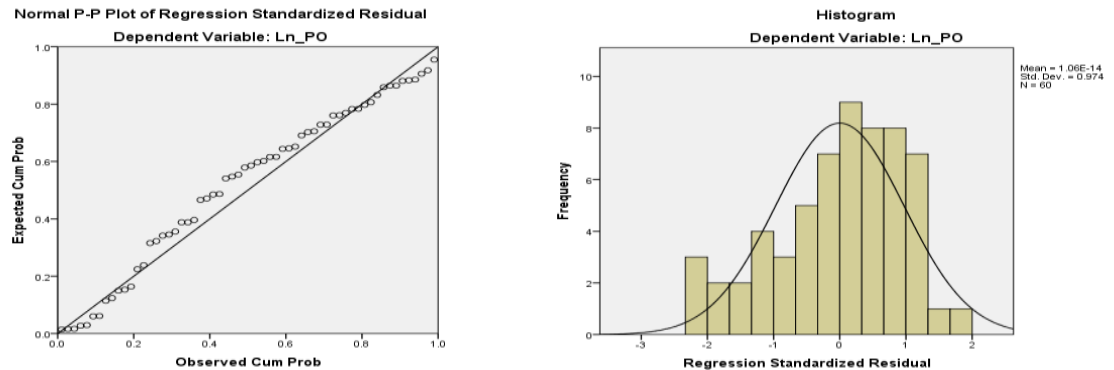

Figure 1. Normal P-plot and Histogram Normal

In the normal graph, the plot shows that the points are spread out closer to the diagonal line. this shows a normally distributed pattern and the histogram graph shows a normally distributed pattern, where the distribution pattern follows a normal curve pattern. So it can be concluded that the regression model has a normal distribution.

Table 3. One K-S Test

One-Sample Kolmogorov-Smirnov Test

\begin{tabular}{|ll|r|}
\hline \multicolumn{2}{|c|}{} & \multicolumn{1}{|c|}{$\begin{array}{c}\text { Unstandardized } \\
\text { Residual }\end{array}$} \\
\hline $\mathrm{N}$ & Mean & 60 \\
Normal Parameters & .0000000 \\
& Std. & .13341915 \\
Meviation & Absolute & .108 \\
& Positive & .060 \\
& Negative & -.108 \\
Test Statistic & & .108 \\
Asymp. Sig. (2-tailed) & $.076^{\mathrm{c}}$ \\
\hline a. Test distribution is Normal. & \\
b. Calculated from data. & & \\
c. Lilliefors Significance Correction. &
\end{tabular}

Based on statistical tests, it shows that the Kolmogorov-Smirnov value obtained with a significant level (Asymsp.Sig.(2-tailed)) is 0.076 which is greater than 0.05 so it can be concluded that the regression model meets the assumption of normality.

\section{Multicollinearity Test}

Table 4. Multicolinearity Test

\begin{tabular}{|c|c|c|c|}
\hline \multirow[b]{2}{*}{ Model } & \multicolumn{2}{|c|}{ Collinearity Statistics } & \multirow[t]{2}{*}{ Keterangan } \\
\hline & Tolerance & VIF & \\
\hline $\begin{array}{ll}1 \text { (Constant) } \\
\text { Ln Current Ratio (X1) } \\
\text { Ln Debt to Equity Ratio (X2) } \\
\text { Ln Return on Asset (X3) }\end{array}$ & $\begin{array}{l}.790 \\
.427 \\
.463\end{array}$ & $\begin{array}{l}1.266 \\
2.344 \\
2.158\end{array}$ & $\begin{array}{l}\text { Not Multicollinearity occurred } \\
\text { Not Multicollinearity occurred } \\
\text { Not Multicollinearity occurred }\end{array}$ \\
\hline
\end{tabular}

a. Dependent Variable: Peringkat Obligasi (Y)

Based on the multicollinearity test above, the variables Ln Current Ratio, Ln Debt to Equity Ratio, and Ln Return on Assets have a tolerance value $>0.10$ and a VIF value $<10.00$ so it can be concluded that the independent variables used in this study are not mutually exclusive. correlated or not multicollinearity occurred.

\section{Heteroscedasticity Test}




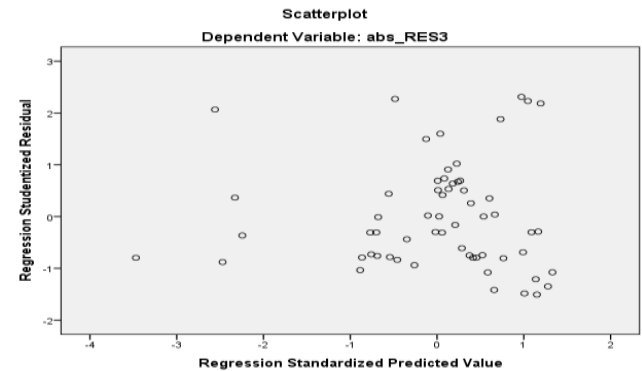

Figure 2. Scatterplot

Based on the results of the heteroscedasticity test using the scatterplot graph above, it is known that the points spread randomly or do not form a certain pattern and are spread both above and below the 0 points on the $\mathrm{Y}$ axis so it can be concluded that there is no heteroscedasticity in the regression model used in this study.

Table 5. Heteroscedasticity Test

\begin{tabular}{|ll|c|c|c|}
\hline Model & $\mathrm{t}$ & Sig. & Keterangan \\
\hline 1 & (Constant) & .989 & .327 & \\
& Ln Current Ratio (X1) & -.027 & .978 & Not Heteroscedasticity occurred \\
& Ln Debt to Equity Ratio (X2) & .225 & .823 & Not Heteroscedasticity occurred \\
& Ln Return on Asset (X3) & .993 & .325 & Not Heteroscedasticity occurred \\
\hline
\end{tabular}

a. Dependent Variable: Abs_RES2 (Y)

Based statistical testing shows that the variables Ln Current Ratio, Ln Debt to Equity Ratio, and Ln Return on Assets have a significance value greater than 0.05 which means that the regression model used does not occur.

\section{Autocorrelation Test}

Table 6. Autocorrelation Test Model Summary ${ }^{\mathrm{b}}$

\begin{tabular}{|c|c|c|c|c|c|}
\hline Model & R & R Square & Adjusted R Square & $\begin{array}{c}\text { Std. Error of the } \\
\text { Estimate }\end{array}$ & Durbin-Watson \\
\hline 1 & $.782^{\mathrm{a}}$ & .612 & .591 & .09140 & 2.098 \\
\hline
\end{tabular}

a. Predictors: (Constant), Ln_ROA, Ln_CR, Ln_DER

b. Dependent Variable: Ln_PO

Based on the autocorrelation test, the Durbin-Watson value is 2,098 where the value is greater than du (1.6889) and smaller than 4-du (2.3111), which means that there is no autocorrelation in this research model.

\section{Simultaneous Significant Test (Statistical Test F)}

Table 7. Simultaneous Significant Test

\begin{tabular}{|ll|r|r|r|r|r|}
\hline Model & & Sum of Squares & df & Mean Square & F & Sig. \\
\hline 1 & Regression & .800 & 3 & .267 & 14.224 & $.000^{\mathrm{b}}$ \\
& Residual & 1.050 & 56 & .019 & & \\
& Total & 1.851 & 59 & & & \\
& & & & \\
\hline
\end{tabular}

a. Dependent Variable: Ln_PO

b. Predictors: (Constant), Ln_DER, Ln_CR, Ln_ROA

Based on table 7 it can be seen that the Fcount value shows a value of 14,224 with an Ftable value of 8.57 with df numerator $=3$, df denominator $=57$ and significant level $=0.05$ so that the results obtained $($ Fcount $=14,224)>($ Ftable $=8,57)$ and $($ significant value $=0.000)<0.05$, which means Ln Current Ratio, Ln Debt to Equity Ratio, and Ln Return On Assets simultaneously affect the Ln Bond Rating of Financial Sector Companies Listed on the Indonesia Stock Exchange

Individual Parameter Significant Test (Test Statistics t)

Table 8. Individual Parameter Significant Test

\begin{tabular}{|c|c|c|c|c|c|}
\hline \multirow{2}{*}{ Model } & \multicolumn{2}{|c|}{ Unstandardized Coefficients } & $\begin{array}{c}\text { Standardized } \\
\text { Coefficients }\end{array}$ & \multirow{2}{*}{ S Sig. } \\
\cline { 2 - 4 } & B & Std. Error & Beta & & \\
\hline
\end{tabular}




\section{Journal of Management Science (JMAS)}

Volume 4. No. 4 October 2021, pp 106-112

e-ISSN: 2684-9747

https://iocscience.org/ejournal/index.php/JMAS

\begin{tabular}{|ll|r|r|r|r|r|}
\hline 1 & (Constant) & 2.775 & .147 & & 18.877 & .000 \\
& Ln_CR & .972 & .222 & .496 & 4.376 & .000 \\
& Ln_DER & .161 & .046 & .523 & 3.534 & .001 \\
& Ln_ROA & .128 & .038 & .519 & 3.365 & .001 \\
\hline
\end{tabular}

a. Dependent Variable: Ln_PO

Based on the statistical test above, the keys are as follows:

Ln Current Ratio is obtained (tcount $=4.376)>($ ttable $=2.003)$ and has (significant value $=0.000)$ $<0.05$ so it can be interpreted that the Current Ratio has a significant positive effect on Bond Ratings in Financial Sector Companies Listed on the Stock Exchange Indonesia 2016 -2019.

Ln Debt to Equity Ratio is obtained (tcount $=3.534)>($ ttable $=2.003)$ and has (significant value $=$ $0.001)<0.05$ so it can be interpreted that the Debt to Equity Ratio has a significant positive effect on Bond Ratings in Financial Sector Companies that Listed on the Indonesia Stock Exchange 2016-2019.

Ln Asset Return obtained (tcount $=3.365)>($ ttable $=2.003)$ and has $($ significant value $=0.001)<0.05$ so it can be interpreted that Asset Return has a significant positive effect on Bond Ratings in Financial Sector Companies Listed on the Exchange Indonesian Securities 2016-2019.

Based on Table 3.7, it can be seen that the results of the multiple linear regression equation formed are: Ln Bond Rating $=2.775+0.972$ Ln Current Ratio + 0.161 Ln Debt to Equity Ratio + 0.128 Ln Return on Assets

\section{Coefficient of Determination Test $\left(\mathbf{R}^{2}\right)$}

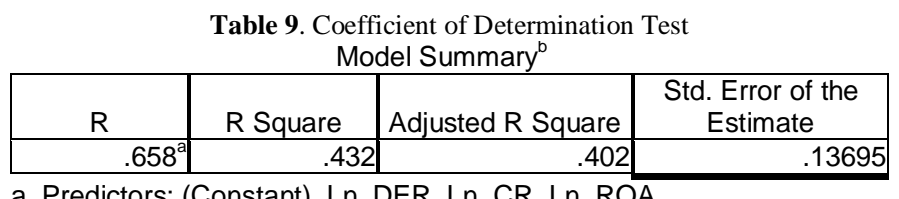

a. Predictors: (Constant), Ln_DER, Ln_CR, Ln_ROA

b. Dependent Variable: Ln_PO

Table 9 shows that the Adjusted R Square value is 0.402 or $40.2 \%$ which means that the percentage of the influence of Ln Current Ratio, Ln Debt to Equity Ratio, and Ln Return on Assets to Ln Bond Rating While the rest is based on $59.8 \%$ influenced by other variables which were not investigated in this study.

\section{Conclusion}

Simultaneously, the independent variables studied have an influence on bond ratings and partially each variable does not have a positive effect on bond ratings for financial sector companies listed on the Indonesia Stock Exchange in 2016-2019. bond bonds can also be explained by the independent variables studied by $40.2 \%$ and ratings by other variables not examined.

\section{References}

Y. R. Yovanda, “Obligasi Adira Finance Dapat Peringkat Tertinggi dari Pefindo," Sindonews, Mar. 15, 2017.

Y. Galvan and C. Sanny, "Rating Bank Woori Saudara dikerek Pefindo," Kontan.co.id, Mar. 15, 2018.

Noviani and Ana, "GAGAL BAYAR: Peringkat Bima Multi Finance Diturunkan Jadi idD," Bisnis.com, Jul. 15, 2017.

S. Hidayat, "Piutang kartu kredit penyebab laporan keuangan Bank Bukopin berubah," Kontan.co.id, May 01, 2018.

emiten news, "Pefindo Naikkan Peringkat PT Bank Woori Saudara Indonesia 1906 (SDRA) Jadi “idAAA," Emitennews, Mar. 13, 2019.

Hery, Balance Scorecard For Business. Jakarta: PT Grasindo, 2017.

I. Ghozali, Aplikasi Analisis Multivariete Dengan Program IBM SPSS 23. Badan Penerbit Universitas Diponegoro, 2017.

Kasmir, Analisis Laporan Keuangan. Depok: PT Rajagrafindo Persada, 2019.

Hidayat and W. Wastam, "Pengaruh Leverage Dan Likuiditas Terhadap Peringkat Obligasi : Studi Kasus Perusahaan Non Keuangan Di Indonesia," J. Ris. Manaj. dan Bisnis Fak. Ekon. UNIAT, vol. 3 no.3, pp. 387-394, 2018.

N. M. S. K. Sari and I. B. Badjra, "Pengaruh Likuiditas, Ukuran Perusahaan, Leverage dan Jaminan Terhadap Peringat Obligasi Pada Sektor Keuangan,” E-Jurnal Manaj. Unud, vol. 5 No.8, pp. 5041-5069, 2016.

Vina, “Analisis Pengaruh Reputasi Audior, Umur Obligasi, Likuiditas, Growth, dan Produktivitas Perusahaan Terhadap Peringkat Obligasi Pada PErtumbuhan Go Public Yang Terdaftar Di Bursa Efek Indonesia," J. Akunt. Bisnis, vol. 15. No.1, pp. 2541-5204, 2017.

D. P. O. S. Saputri and I. B. A. Purbawangsa, "Pengaruh Leverage, Profitabilitas, Pertumbuhan Perusahaan, Dan Jaminan Terhadap Peringkat Obligasi Sektor Jasa Di Bursa Efek Indonesia.," E-Jurnal Manaj. Unud, vol. 5. No.6, pp.

111 
3706-3705, 2016

H. M. Narandika, F. Sanusi, and I. Utami, "Pengaruh Rasio Profitabilitas Dan Rasio Leverage Terhadap Peringkat Obligasi (Studi Empiris pada Perusahaan Sub Sektor Perbankan YAng Terdaftar di Bursa Efek Indonesia Periode 2010-2015)," J. Manaj. dan Bisnis, vol. 9. No.1, 2016.

W. Tetty,"Pengaruh Rasio Leverage dan Rasio Profitabilitas Terhadap Peringkat Obligasi", J. Komp, vol. 8 No.1, pp 2088-6268, 2016.

K. A. Putri, Kharrunisa and J. D. Vaya, "Pengaruh Likuiditas, Leverage dan Pertumbuhan Perusahaan Terhadap Peringkat Obligasi", E-Peoceeding of Manaj, vol. 4. No.1, pp. 2355-9357, 2017 